\title{
Dampak Problem Based Learning terhadap Pemahaman Konsep Ditinjau dari Gaya Berpikir Siswa pada Mata Pelajaran Fisika
}

\author{
A.Halim ${ }^{1, a)}$, Suriana $^{2}$, Mursal $^{3}$ \\ ${ }^{1}$ Program studi Pendidikan Fisika, FKIP, Universitas Syiah Kuala, Aceh. \\ ${ }^{2}$ Universitas Islam Negeri Ar-Raniry (UIN), Banda Aceh. \\ ${ }^{3}$ Jurusan Fisika FMIPA Universitas Syiah Kuala Banda Aceh. \\ Email: a)bdlhalim@yahoo.com
}

\begin{abstract}
This study aims to determine students's increased understanding of the concept in terms of thinking style after the implementation of the model-based PBL experiments on matter and energy. This study uses quasi-experimental methods, the shape of nonequivalent control group design involving two study groups namely experimental and control classes were held in MAN Rukoh Banda Aceh class XI the first semester of academic year 2015/2016 consisting of 24 students experiment class and 25 students control class. Data collection instruments; 1) Tests to see increased understanding of the concept; 2) Test thinking style questionnaire to determine the type of thinking style the students to absorb information. The results showed that: 1) There is an increased understanding the concept of students with the application of model PBL learning based experiment than higher conventional learning seen from N-Gain both classes, reaching $71 \%$ higher category for experimental class and $32 \%$ for control class. 2) On this kind of thinking style random abstract experimental class is better than the control class. On this kind of thinking style concrete sequential increase understanding concept of experimental class is better than the control class. On this kind of thinking style abstract sequential increase understanding of the concept experimental class is better than the control class. On this kind of thinking style concrete random improved understanding concept of control class reached (4.00) while the experimental group (0.00) for the experimental class did not have a concrete random thinking styles.
\end{abstract}

Keywords: Model PBL Based Experiment, Concept Undertanding, Thinking Style.

\begin{abstract}
Abstrak
Terdapat empat jenis gaya berpikir siswa yang digunakan dalam penelitian, yaitu Sekuensial Konkret (SK), Sekuensial Abstrak (SA), Acak Konkret (AK), dan Acak Abstrak (AA). Berdasarkan empat jenis gaya berpikir tersebut, jenis gaya berpikir yang paling tinggi terjadi peningkatan pemahaman konsep fisika dan indikator pemahaman manakah paling tinggi peningkatannya. Inilah tujuan yang ingin diketahui dari hasil penelitian yang dilakukan pada 24 siswa MAN Rukoh Banda Aceh kelas XI sebanyak 24 siswa untuk kelas eksperimen dan 25 siswa kelas kontrol setelah dilakukan perlakuan dengan model PBL berbasis eksperimen. Penelitian ini menggunakan metode quasi experimental, dengan desain nonequivalent control group design dan pengumpulan data menggunakan; tes untuk melihat peningkatan pemahaman konsep; dan angket untuk melihat jenis gaya berpikir yang dimiliki siswa. Hasil penelitian menunjukkan bahwa indikator pemahaman konsep "Translasi" terjadi peningkatan tertinggi
\end{abstract}


pada siswa yang memiliki jenis gaya berpikir "Sekuensial Konkret (SK)" pada kelompok eksperimen, sebaliknya untuk siswa yang memiliki jenis gaya berpikir "Sekuensial Abstrak (SA)" indikator pemahaman konsep tertinggi adalah "Translasi", ini terjadi pada kelas kontrol.

Kata-kata Kunci: Model Pembelajaran PBL Berbasis Eksperimen, Pemahaman Konsep, Gaya Berpikir.

\section{PENDAHULUAN}

Permasalahan yang sering dihadapi siswa dalam pembelajaran adalah siswa kurang memahami pelajaran fisika dikarenakan siswa malas belajar dan ketika pembelajaran berlangsung siswa tidak mau bertanya dan tidak memiliki rasa penasaran atau rasa ingin tahu terhadap materi pelajaran yang diajarkan guru sehingga sebagian siswa tidak memahami isi materi pelajaran tersebut, hal ini diakibatkan siswa kurang berpikir sehingga berimbas pada hasil belajar siswa khususnya pada pemahaman konsep belajar siswa. Berdasarkan hasil wawancara dengan guru bidang studi terdapat bahwa hanya 10 persen dari keseluruhan siswa yang menyukai pelajaran fisika, dan siswa yang benar-benar menyukai fisika dapat memenangkan beberapa kejuaraan cerdas cermat, olimpiade fisika, dan sebagainya baik itu tingkat provinsi maupun tingkat nasional.

MAN Rukoh Banda Aceh merupakan salah satu sekolah di Banda Aceh dengan akreditasi A oleh BAN-PT, tidak heran jika prestasi-prestasi yang diraih diberbagai bidang pun cukup banyak, salah satunya bidang olah raga dan kesenian yang selalu jadi kebanggaan dari sekolah ini, namun jika kita lihat prestasi dari bidang pendidikan dan akademik sangat disayangkan hanya sebagian kecil dari mereka yang mampu meraihnya, khususnya bidang fisika seperti yang telah dijelaskan di atas. Hal ini bisa saja disebabkan oleh beberapa hal diantaranya: kurangnya rasa ingin tahu, lemahnya daya ingat, kurangnya motivasi, malas bertanya, sukar untuk berpikir, kurangnya informasi, dan hanya berharap informasi dari guru, hal seperti inilah yang dapat mempengaruhi pengetahuan siswa dalam memahami suatu pelajaran yang diajarkan guru sehingga berimbas pada hasil belajar siswa khususnya pada pemahaman konsep siswa.

Kurangnya pemahaman siswa dalam memahami pelajaran dapat kita lihat dari hasil ulangan harian, ujian semester dan nilai UN. Hasil analisis UN pada materi usaha dan energi berdasarkan data kemendikbud, (2012, 2013 dan 2014). Pada tahun ajaran 2011/2012 berada pada peringkat 7 terbawah dari 31 indikator dengan nilai tingkat Sekolah (76,92); tingkat Kabupaten/Kota sebesar (80,53); tingkat Propinsi sebesar $(76,64)$ dan tingkat Nasional sebesar $(82,01)$. Pada Hasil analisis UN Pada tahun ajaran 2012/2013 berada pada peringkat 11 terbawah dari 31 indikator dengan nilai tingkat Sekolah $(79,75)$; tingkat Kabupaten/Kota sebesar $(87,12)$; tingkat Propinsi sebesar $(66,25)$ dan tingkat Nasional sebesar $(66,29)$. Pada tahun ajaran 2013/2014 berada pada peringkat 1 terbawah dari 31 indikator dengan nilai tingkat Sekolah $(22,73)$; tingkat Kabupaten/Kota sebesar $(48,24)$; tingkat Propinsi sebesar $(34,24)$ dan tingkat Nasional sebesar $(36,38)$.

Meningkatnya pemahaman konsep siswa dalam belajar tergantung bagaimana siswa itu berpikir dalam mengolah informasi, untuk itu siswa membutuhkan cara-cara berpikir yang disebut sebagai gaya berpikir, jika siswa yang memiliki gaya berpikir tinggi akan dapat memecahkan masalah yang diberikan guru dengan baik sehingga dapat meningkatkan pemahaman konsepnya, dan juga sebaliknya jika siswa yang memiliki gaya berpikir rendah kurang mampu menyelesaikan masalah dengan baik sehingga mengakibatkan pemahaman konsepnya rendah. Selain itu, meningkatanya pemahaman konsep siswa tergantung bagaimana seorang guru dalam mengelola pembelajaran, peranan seorang guru dalam proses belajar mengajar fisika tidak hanya memberikan informasi kepada siswa tetapi juga harus menerapkan prinsip-prinsip ilmu pengetahuan yang berorientasi kepada observasi dan eksperimen, guru harus memperhatikan karakteristik siswa dalam belajar, setiap siswa memiliki gaya belajar berbeda-beda sehingga guru harus memiliki kemampuan dalam memvariasikan model pembelajaran sesuai dengan karakteristik siswa, sehingga siswa tidak bosan dalam belajar.

Oleh karena itu, penulis berinisiatif untuk menerapkan metode pembelajaran yang biasa digunakan oleh guru khususnya fisika dengan model pembelajaran lain, yaitu model pembelajaran

Problem Based Learning (PBL) berbasis eksperimen. Pembelajaran PBL merupakan model pembelajaran yang memacu siswa untuk berpikir kritis dan kreatif serta mengembangkan ide-ide 
sehingga bisa memecahkan masalah melalui eksperimen Duch, dkk dalam Abidin (2014: 160). Eksperimen yang dimaksud adalah pembelajaran dengan menggunakan alat dan bahan baik secara individu maupun kelompok sehigga siswa dapat mengembangkan ide-ide siswa (Mulyasa, 2005: 110).

Penggabungan kedua pembelajaran ini dilakukan untuk mempermudah siswa memahami permasalahan yang diberikan guru sehingga dapat meningkatkan pemahaman konsep siswa, dan kolaborasi kedua pembelajaran ini didasarkan pada langkah-langkah model PBL mengandung unsur eksperimen, yaitu pada langkah kedua dalam pembelajaran PBL dimana pada kegiatan ini, guru dituntut untuk melakukan kegiatan mengorganisasikan peserta didik untuk meneliti (Suprijono, 2011: 74). Selanjutnya Nata (2009: 243) mengatakan bahwa model pembelajaran PBL adalah salah satu model pembelajaran yang berpusat pada peserta didik dengan cara menghadapkan para peserta didik tersebut dengan berbagai masalah yang dihadapi dalam kehidupannya.

Beberapa hasil penelitian terdahulu telah membuktikan keefektifan penerapan model pembelajaran PBL dan eksperimen dalam pembelajaran khususnya fisika dan pembelajaran ini sudah banyak dilakukan diberbagai daerah, lembaga pendidikan, instansi dan sebagainya yang secara umum bertujuan untuk memperbaiki mutu pendidikan dan pembelajaran, dan secara khusus hal ini hanya bertujuan untuk melatih siswa dalam memecahkan masalah, sehingga siswa secara mandiri dituntut untuk lebih kreatif (Eldy \& Sulaiman, 2013), kritis (Sulaiman, 2013; Paramitha, dkk, 2014), berinovasi dan dapat meningkatkan pemahaman konsep (Dwi dkk, 2013; Utomo dkk, 2014; Sahin, 2010) dalam pembelajaran, bukan hanya itu, model PBL juga dapat mempengaruhi hasil belajar siswa (Oktaviani, dkk, 2014), motivasi dan minat (Husni, 2015; Zaraturrahmi, 2016; Hadiya, 2014), keterampilan proses sains (Rusnayati \& Prima, 2011) serta keyakinan siswa dalam belajar (Selcuk, 2010). Selain itu, penelitian lain juga membuktikan keefektifan pembelajaran eksperimen dalam meningkatkan hasil belajar siswa (Gimin, 2009) dan pemehaman konsep siswa (Gumilar, 2013).

Penelitian tentang peninjauan hasil belajar terhadap gaya berpikir sudah banyak dilakukan diberbagai bidang pendidikan baik dengan menggunakan model, metode, pendekatan (Sugiyatno, 2010; Sitompul, 2013; Fitriani, 2015; Bancong, 2014; Xie dkk, 2013), atau hanya sekedar melihat perbedaan dan hubungan antara gaya berpikir dengan berpikir kritis siswa (Abdi, 2012), kemampuan perhatian terhadap pelajaran (Piaw, 2014), prestasi belajar (Sharma \& Neetu, 2011), jenis kelamin (Bawaneh dkk, 2011), kecerdasan (Beceren \& Atiye, 2010), serta hambatan-hambatan dalam berpikir kreatif dan gaya berpikir (Piaw, 2011).

\section{METODE PENELITIAN}

Penelitian ini menggunakan metode penelitian Quasi Experimental, dengan bentuk Nonequivalent Control Group Design. Penelitian Quasi Experimental melibatkan dua kelas atau dua kelompok belajar yaitu kelas eksperimen dan kelas kontrol dimana sampel kedua kelas ini tidak dipilih secara random (Sugiyono, 2009: 116).

TABEL 1. Desain Penelitian

\begin{tabular}{|c|c|c|c|}
\hline Kelas & Tes Awa & Perlakuan & Tes Akhir \\
\hline Eksperimen & O1 & $\mathrm{X} 1$ & $\mathrm{O} 2$ \\
\hline Kontrol & $\mathrm{O} 3$ & $\mathrm{X} 2$ & $\mathrm{O} 4$ \\
\hline
\end{tabular}

(Sumber: Sugiyono, 2009)

Keterangan:

O1 dan O3: Tes awal kelas eksperimen dan kontrol

O2 dan O4: Tes akhir kelas eksperimen dan kontrol

$\mathrm{X} 1$ : Perlakuan dengan penerapan PBL berbasis eksperimen

$\mathrm{X} 2$ : Perlakuan dengan penerapan motode konvensional

Teknik pengambilan sampel ini purposive sampling yaitu dengan mengambil dua kelas yang nilai rata-ratanya sama atau hampir sama pada nilai ulangan harian sebelumnya. sehingga yang dijadikan sampelnya adalah dua kelas, yaitu kelas XI-MIA2 dan XI-MIA3. Sampel pertama merupakan kelas yang diajarkan dengan menggunakan model pembelajaran PBL berbasis eksperimen sebagai kelas 
eksperimen, sampel kedua merupakan kelas yang diajarkan dengan pembelajaran konvensional sebagai kelas kontrol. Penelitian ini dilaksanakan di MAN Rukoh Banda Aceh pada siswa kelas XI MIA, MAN Rukoh terletak di Jalan Rukoh Utama, kecamatan Darussalam, kota Banda Aceh.

Instrumen pengumpulan data yang digunakan dalam penelitian ini ada dua yaitu tes pemahaman konsep dan tes gaya berpikir. Tes pemahaman konsep diukur dengan soal pelihan ganda yang disusun berdasarkan indikator pemahaman yaitu translasi, interprestasi dan ekstrapolasi (sudjana, 2011: 24). Tes pemahaman konsep dilakukan dua kali yaitu tes awal dan tes akhir. Sedangkan tes gaya berpikir merupakan tes yang diberikan kepada siswa untuk mengetahui jenis gaya berpikir masing-masing siswa dalam belajar. Gaya berpikir diukur dengan menggunakan kuesioner tes gaya berpikir yang dikembangkan oleh Gregorc dalam (Bobbi \& Mike, 2011:125) dimana dalam tes ini menggunakan 15 kelompok kata dimana dalam satu kelompok terdiri dari 4 kata mencerminkan kepribaian masing-masing. Dalam penelitian ini ada empat gaya berpikir yang akan dilihat yaitu: Sekuensial Konkret (SK), Sekuensial Abstrak (SA), Acak Konkret (AK), dan Acak Abstrak (AA).

Teknik analisis data tes pemahaman konsep dilakukan dengan penghitungan N-Gain, Gain yang diperoleh dinormalisasi oleh selisih antara skor maksimal dengan skor tes awal. Perubahan yang terjadi sebelum dan sesudah pembelajaran dihitung dengan rumus Indeks-Gain yang dikembangkan oleh Hake (1999: 1).

$$
\text { Indeks }- \text { Gain }=\frac{S_{\text {post }}-S_{\text {pre }}}{S_{\text {max }}-S_{\text {pre }}} \times 100
$$

Nilai Indeks-Gain yang diperoleh digunakan untuk melihat peningkatan pemahaman konsep siswa sebelum dan sesudah belajar dengan model pembelajaran PBL berbasis eksperimen. Klasifikasi nilai $\mathrm{N}$-Gain, kategori tinggi jika N-Gain $>0,70$; kategori sedang jika $0,30 \leq \mathrm{N}$-Gain $\leq 0,70$; dan kategori rendah jika $\mathrm{N}$-Gain $<0,30$.

Tes gaya berpikir dianalisis berdasarkan teori yang dikembangkan oleh Gregorc dalam (Bobbi \& Mike, 2011:126) dimana analisis tes ini dilakukan setelah mendapatkan jawaban dari siswa berdasarkan kuesioner yang telah dibagikan. Jawaban siswa akan dijumlahkan berdasarkan kolom yaitu kolom I memiliki gaya berpikir sekuensial konkret, kolom II memiliki gaya berpikir sekuensial abstrak, kolom III memiliki gaya berpikir acak konkret, dan kolom IV memiliki gaya berpikir acak abstrak. Jumlah masing-masing kelom dikalikan dengan 4, kotak dengan jumlah angka yang terbesar menjelaskan dengan cara apa siswa paling sering mengolah informasi, setelah mendapatkan jawaban dari hasil perkalian maka angkanya dimasukkan dalam grafis, tujuannya untuk melihat lebih jelas jenis gaya berpikir mana yang sering digunakan siswa dalam mengolah informasi atau mendapatkan informasi. Alternatif jawaban dan kesimpulan jenis gaya berpikir dapat dilihat dalam Bobbi dan Mike (2011:126).

\section{HASIL DAN PEMBAHASAN}

Penelitian ini melihat peningkatan pemahaman konsep siswa yang dilakukan sebelum dan sesudah pembelajaran, sebelum pembelajaran tes yang dilakukan adalah tes awal dan sesudah pembelajaran dilakukan tes akhir. Data tes awal, tes akhir dan N-Gain kelas eksperimen dan kelas kontrol dianalisis dengan menggunakan Microsoft Office Excel 2007, dari hasil analisis data tersebut dapat diketahui sejauh mana peningkatan pemahaman konsep belajar siswa sebelum dan sesudah pembelajaran. Hasil analisis tes menunjukkan bahwa secara keseluruhan terdapat perbedaan peningkatan kemampuan pemahaman konsep belajar siswa kelas eksperimen dengan penerapan model PBL berbasis eksperimen dibandingkan siswa kelas kontrol yang mendapatkan pembelajaran secara konvensional. Artinya pemahaman konsep kelas eksperimen lebih baik dibandingkan dengan kelas kontrol, perbandingan ini dapat ditunjukkan dengan adanya perbedaan perolehan nilai rata-rata tes akhir dan $\mathrm{N}$-Gain dari kedua kelas tersebut. Tingginya perolehan skor tes akhir dan N-Gain kelas eksperimen dikarenakan pembelajaran PBL berbasis eksperimen dapat memberikan kesempatan kepada siswa untuk memecahkan masalah baik secara individual ataupun kelompok, hal ini sesuai dengan yang diutarakan oleh Abidin (2014: 158) bahwa PBL merupakan suatu model yang menantang peserta didik untuk "belajar bagaimana belajar, bekerja secara kelompok untuk mencari solusi dari permasalahan dunia nyata. 
Selain itu, hasil analisis juga dapat membuktikan bahwa pembelajaran PBL berbasis eksperimen dapat meningkatkan pemahaman konsep siswa. Hal ini sesuai dengan penelitian Utomo, dkk (2014) menyebutkan bahwa model pembelajaran PBL dapat mempengaruhi pemahaman konsep dan kemampuan berpikir kreatif siswa. Dan Gumilar (2013) berdasarkan hasil pengujian statistik menunjukkan bahwa pembelajaran dengan metode eksperimen nyata-virtual lebih signifikan dalam meningkatkan pemahaman konsep dan keterampilan berpikir siswa. Berdasarkan data kategori $\mathrm{N}$ Gain untuk pemahaman konsep kelas eksperimen dan kelas kontrol setiap siswa disajikan pada tabel berikut.

TABEL 2. Kategori N-Gain Pemahaman Konsep Kelas Eksperimen dan Kontrol

\begin{tabular}{ccccc}
\hline \multirow{2}{*}{ Kategori N-Gain } & \multicolumn{2}{c}{ Eksperimen } & \multicolumn{2}{c}{ Kontrol } \\
& Frekuensi & Persentase & Frekuensi & Persentase \\
\hline Tinggi & 17 & 71 & 8 & 32 \\
Sedang & 5 & 21 & 15 & 60 \\
Rendah & 2 & 8 & 2 & 8 \\
\hline
\end{tabular}

Kelas eksperimen dan kontrol memiliki jenis gaya berpikir yang berbeda-beda, kelas eksperimen memiliki tiga jenis gaya berpikir yaitu gaya berpikir sekuensial konkret, sekuensial abstrak dan acak abstrak, sedangkan siswa di kelas kontrol memiliki empat jenis gaya berpikir yaitu sekuensial konkret, sekuensial abstrak, acak konkret dan acak abstrak. Namun dari empat jenis gaya berpikir baik kelas eksperimen dan kontrol ternyata gaya berpikir acak abstraklah yang paling dominan dalam meningkatkan pemahaman konsep siswa. Hal ini dikarenakan gaya berpikir acak abstrak merupakan pemikir pada dunia perasaan dan emosi dan proses penyerapan informasi diatur secara refleksi (penuh pertimbangan), pemikir acak abstrak mengingat informasi dengan baik apabila informasi yang didapatkan merupakan informasi yang dipersonifikasikan, bagi pemikir acak abstrak pesan dan emosi dapat meningkatkan dan mempengaruhi belajar mereka (Bobbi \& Mike, 2011: 132).

Peningkatan pemahaman konsep berdasarkan jenis gaya berpikir siswa terlihat bahwa kedua kelas dominan memiliki jenis gaya berpikir acak abstrak, hal ini menunjukkan bahwa siswa MAN Rukoh Banda Aceh didominasi oleh pemikir acak abstrak yang merupakan pemikir dengan dunia nyata dan emosi, pemikir acak abstrak ini bekerja dengan baik dalam situasi-situasi yang kreatif dan harus bekerja lebih giat dalam situasi yang lebih teratur, begitu juga dalam belajar siswa yang memiliki gaya berpikir acak abstrak lebih kreatif dan mereka hai ini sesuai dengan penelitian Bancong (2014: 16) Gaya berpikir Acak Abstrak (AA) lebih kreatif dalam merencanakan dan menyelesaikan masalah fisika. Penelitian lain Sugiyatno, (2010: 4) menunjukkan tidak ada pengaruh gaya berpikir siswa terhadap prestasi belajar dan gaya berpikir acak mendapatkan prestasi lebih tinggi dari pada gaya berpikir sekuensial. Berbeda halnya dengan penelitian Fitriani (2015: 112) menunjukkan bahwa siswa yang memiliki gaya berpikir sekuensial konkret menghasilkan prestasi belajar lebih baik dibandingkan dengan siswa yang berpikir sekuensial konkret, acak konkret dan acak abstrak. Sedangkan siswa yang memiliki gaya berpikir acak abstrak menghasilkan prestasi belajar sama baiknya dengan gaya berpikir sekuensial konkret, acak konkret, penelitian ini kemungkinan dipengaruhi oleh model yang diterapkan atau bentuk instrumen yang digunakan.

Indikator pemahaman konsep ditinjau dari gaya berpikir yang digunakan dalam penelitian ini adalah translasi, interpretasi dan eksplorasi yang merupakan adopsi dari ranah kognitif Bloom (Sudjana, 2011: 24), dan setiap indikator memiliki tiga kategori yaitu kategori tinggi, sedang dan rendah, dari indikator inilah yang akan dilihat peningkatan pemahaman disetiap jenis gaya berpikir yang dimiliki siswa. Pada jenis gaya berpikir sekuensial konkret terlihat bahwa peningkatan pemahaman pada setiap indikator pemahaman konsep dikelas eksperimen dan kontrol terdapat perbedaan, pada kategori tinggi peningkatan pemahaman kelas eksperimen lebih besar dari pada kelas kontrol. Hal ini dikarenakan pemikir sekuensial konkret juga merupakan pemikir yang berpegang pada kenyataan dan proses informasi dengan cara yang teratur, linear, dan sekuensial. Bagi pemikir bergaya ini, realitas terdiri dari apa yang dapat mereka ketahui melalui indra fisik meraka yaitu indra penglihatan, peraba, pendengar, perasa dan penciuman. Pemikir sekuensial biasanya memiliki pengarahan dan prosedur khusus (Mahmud, 2010: 35). Pemikir SK dengan berpegang pada kenyataan dan proses informasi sehingga mampu menterjemah, menghubungkan dan menganalisis suatu lambang dan mengubahnya dalam bentuk lain yang mudah dipahaminya 
(Sudjana, 2011: 24). Peningkatan pemahaman konsep ditinjau dari gaya berpikir sekuensial konkret selengkapnya dapat dilihat pada GAMBAR 1.

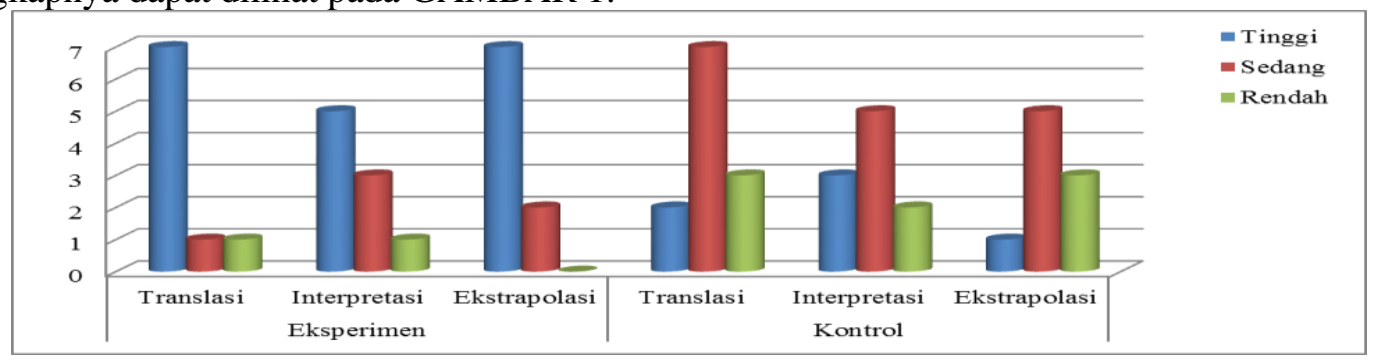

GAMBAR 1. Peningkatan Pemahaman Konsep pada Jenis Gaya Berpikir Sekuensial Konkret

Pada jenis gaya berpikir sekuensial abstrak terlihat bahwa peningkatan pemahaman pada setiap indikator pemahaman konsep dikelas eksperimen dan kontrol juga terdapat perbedaan, pada setiap kategori peningkatan pemahaman kelas eksperimen lebih besar dari pada kelas kontrol, hal ini disebabkan pemikir sekuensial abtrak merupakan pemikir dunia teori metafisis dan pemikiran yang abstrak, pemikir sekuensial abstrak lebih suka berfikir dalam konseptual dan menganalisis informasi dengan membaca sehingga proses dibentuk secara logis, rasional dan intelektual (Mahmud, 2010: 35). Peningkatan pemahaman konsep ditinjau dari gaya berpikir sekuensial abstrak selengkapnya dapat dilihat pada GAMBAR 2.

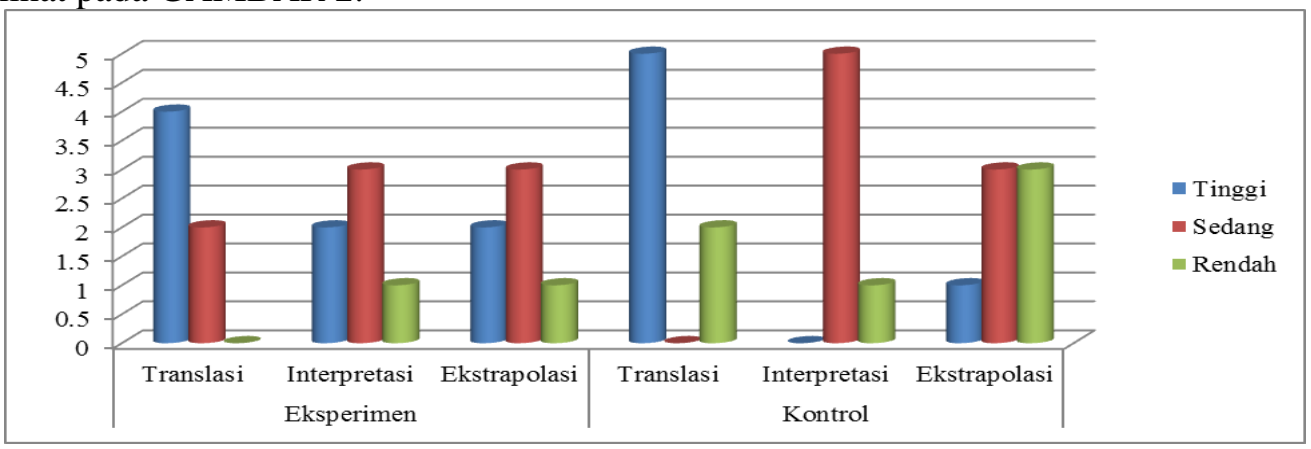

GAMBAR 2. Peningkatan Pemahaman Konsep pada Jenis Gaya Berpikir Sekuensial Abstrak

Pada jenis gaya berpikir acak abstrak terlihat bahwa peningkatan pemahaman pada setiap indikator pemahaman konsep dikelas eksperimen dan kontrol juga terdapat perbedaan, pada kategori tinggi peningkatan pemahaman kelas eksperimen lebih besar dari pada kelas kontrol, hal ini disebabkan pemikir acak abstrak dapat menyerap ide-ide, informasi, kesan dan mengaturnya dengan refleksi, sehingga mampu menerjemahkan dan menghubungkan suatu konsep dengan konsep lainnya atau menghubungkan bagian-bagian terdahulu dengan yang diketahui berikutnya, atau menghubungkan beberapa bagian dari grafis dengan kejadian, membedakan yang pokok dan yang bukan pokok (Sudjana, 2011: 24). Peningkatan pemahaman konsep ditinjau dari gaya berpikir acak abstrak selengkapnya dapat dilihat pada GAMBAR 3.

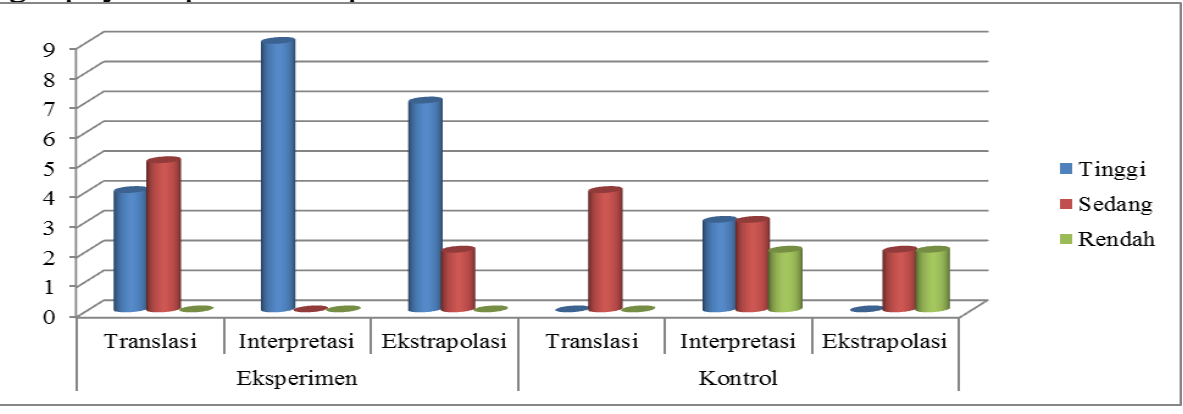

GAMBAR 3. Peningkatan Pemahaman Konsep pada Jenis Gaya Berpikir Acak Abstrak

Pada jenis gaya berpikir acak konkret terlihat bahwa peningkatan pemahaman pada setiap indikator pemahaman konsep dikelas eksperimen adalah nol (0) dikenakan kelas eksperimen tidak memiliki gaya berpikir acak konkret, sedangkan kelas kontrol terlihat bahwa peningkatan 
pemahaman berdasarkan indikator yang terjadi pada indikator translasi dan ekstepolasi saja, hal ini dikarenakan pemikir acak konkret merupakan pemikir yang berpegang pada kenyataan dan berprilaku kurang terstruktur sehingga proses penyerapan informasi didapatkan dengan menemukan alternatif melalui eksperimen dan mengerjakan sesuatu dengan cara mereka sendiri (Mahmud, 2010: 35). Peningkatan pemahaman konsep ditinjau dari gaya berpikir acak konkret selengkapnya dapat dilihat pada GAMBAR 4.

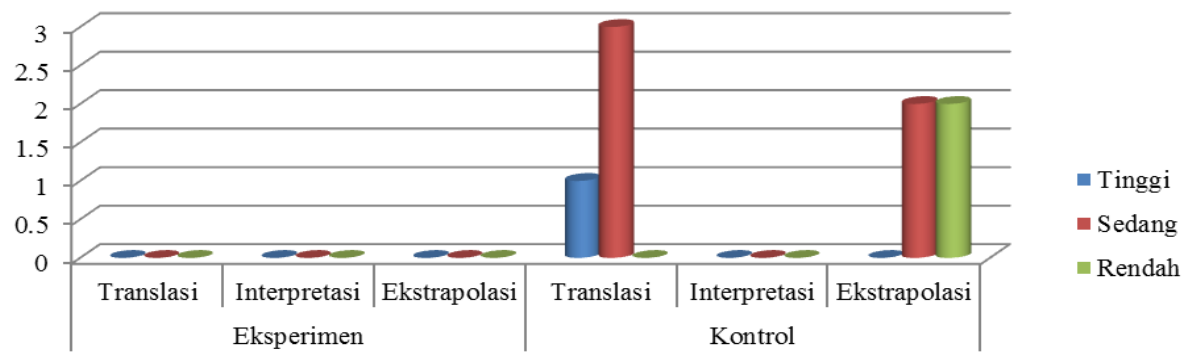

GAMBAR 4. Peningkatan Pemahaman Konsep pada Jenis Gaya Berpikir Acak konkret

\section{KESIMPULAN}

Berdasarkan permasalahan, analisis data, hasil penelitian dan pembahasan yang telah dipaparkan sebelumnya, maka dapat disimpulkan bahwa: (1) Terdapat pengaruh terhadap peningkatan pemahaman konsep siswa dengan pembelajaran PBL berbasis eksperimen. Peningkatan pemahaman konsep kelas eksperimen lebih tinggi dibandingkan dengan kelas kontrol dilihat dari N-Gain kedua kelas yaitu mencapai $(71 \%)$ kategori tinggi untuk kelas eksperimen dan $(32 \%)$ untuk kelas kontrol. (2) Peningkatan pemahaman konsep didominasi oleh siswa pemikir AA baik kelas eksperimen maupun kelas kontrol, pada kelas eksperimen peningkatan pemahaman konsep jenis gaya berpikir AA lebih baik dibandingkan kelas kontrol dengan pencapaian $(7,33)$ kelas eksperimen sedangkan kelas kontrol $(5,25)$. Pada jenis gaya berpikir SK peningkatan pemahaman konsep kelas eksperimen lebih baik dari pada kelas kontrol dengan pencapaian $(5,44)$ kelas eksperimen dan $(4,30)$ kelas kontrol. Peda jenis gaya berpikir SA peningkatan pemahaman konsep kelas eksperimen lebih baik dari pada kelas kontrol dengan pencapaian $(4,67)$ kelas eksperimen dan $(4,57)$ kelas kontrol. Peda jenis gaya berpikir AK peningkatan pemahaman konsep kelas kontrol mencapai $(4,00)$ sedangkan kelas eksperimen $(0,00)$ karena kelas eksperimen tidak memiliki gaya berpikir AK.

\section{REFERENSI}

Abdi, A. 2012. A Study on The Relationship of Thinking Styles of Students and Their Critical Thinking Skills. Procedia - Social and Behavioral Sciences 47: 1719 -1723.

Abidin, Y. 2014. Desain Sistem Pembelajaran dalam Konteks Kurikulum 2013. Bandung: Refika Aditama.

Bancong, H. 2014. Studi Kualitatif Gaya Berpikir Peserta Didik dalam Memecahkan Masalah Fisika. Jurnal Berkala Fisika Indonesia. 6 (1). 1-7.

Bawaneh, A. K. A, Abdul G. K. A, Salmiza S dan Khoo Y. 2011. Jordanian Students' Thinking Styles Based on Herrmann Whole Brain Model. International Journal of Humanities and Social Science. 1. (9).

Beceren, B. O dan Atiye, A. O. 2010. The Comparison of Prospective Preschool Teachers' Thinking Styles and Intelligence Types. Procedia Social and Behavioral Science. 2. (2131-2136).

Bobbi, D dan Mike, H. 2011. Quantum Learning. Bandung: Kaifa.

Dwi, I. M, H. Arif, K. Sentot. 2013. Pengaruh Strategi Problem Based Learning Berbasis ICT Terhadap Pemahaman Konsep Dan Kemampuan Pemecahan Masalah Fisika. 9 (1). Jurnal Pendidikan Fisika Indonesia. Tersedia:

http://journal.unnes.ac.id/nju/index.php/JPFI/article/view/2575. diakses: 23 Agustus 2015 
Eldy, E. F dan F. Sulaiman. 2013. Integrated PBL Approach: Preliminary Findings towards Physics Students' Critical Thinking and Creative-Critical Thinking. International Journal of Humanities and Social Science. (2). 18-25.

Fitriani, N. S, 2015. Eksperimentasi Model Pembelajaran Kooperatif Tipe Think Talk Write (TTW) dan Number Head Together (NHT) dengan Pendekatan Saintifik Disertai Strategi Peta Konsep pada Materi Bilangan Ditinjau dari Gaya Berpikir Siswa Kelas VII SMPN Se-Kota Metro Lampung. Tesis. Universitas Sebelas Maret Surakarta.

Gimin. 2009. Perbedaan Pegaruh Metode Pembelajaran Eksperimen Model Seqip Dan Konvensional Terhadap Hasil Belajar Ipa Ditinjau Dari Kreativitas Siswa (Eksperimen Terhadap Siswa SD Kecamatan Ngadirojo Wonogiri ). Tesis. Surakarta: Program Studi Teknologi Pendidikan, Program Pascasarjana, Universitas Sebelas Maret. (online). Tersedia: http://eprints.uns.ac.id.pdf. Diakses: 15 Mei 2015.

Gumilar, S. 2013. Penerapan Model Pembelajaran Inkuiri dengan Kombinasi Eksperimen NyataVirtual untuk Meningkatkan Pemahaman Konsep dan Keterampilan Berpikir Kritis. Tesis. UPI. (online). Tersedia: http://repository.upi.edu.pdf. Diakses: 15 Mei 2015.

Hadiya, I. 2014. Pengembangan Modul Pembelajaran Suhu dan Kalor Berbasis Masalah Untuk SMA dalam Upaya Meningkatkan Minat Belajar Siswa. Tesis. Tidak Dipublikasi. Program Magister Pendidikan IPA Universitas Syiah Kuala.

Hake, R.R. 1999. Interactive-Engagement versus Traditional Methods: A Six-Thousand-Student Survey of Mechanics Test Data for Introductory Physics Courses. American Journal of Physics. I. 66.

Husni. 2015. Implementasi Pembelajaran Kimia Berbasis Lingkungan dengan Model Problem Based Learning (PBL) untuk Meningkatkan Minat dan Keterampilan Berpikir Kritis Siswa SMA. Tesis. Tidak Dipublikasi. Magister Pendidikan IPA Universitas Syiah Kuala.

Kemendikbud. 2012. Kementrian Pendidikan dan Kebudayaan Republik Indonesia tentang Laporan Hasil Ujian Nasional. Jakarta: BSNP.

Kemendikbud. 2013. Kementrian Pendidikan dan Kebudayaan Republik Indonesia tentang Laporan Hasil Ujian Nasional. Jakarta: BSNP.

Kemendikbud. 2014. Kementrian Pendidikan dan Kebudayaan Republik Indonesia tentang Laporan Hasil Ujian Nasional. Jakarta: BSNP.

Mahmud. 2010. Psikologi Pendidikan. Bandung: Pustaka Setia.

Mulyasa, E. 2005. Menjadi Guru Profesional. Bandung: Remaja Rosdakarya.

Nata, A. 2009. Perspektif Islam Tentang Strategi Pembelajaran. Jakarta: Kencana Prenada Media Group.

Oktaviani, L. Dantes, N. dan Sadia, W. 2014. Pengaruh Model Problem- Based Learning Berbasis Asesmen Kinerja Terhadap Hasil Belajar IPA Ditinjau dari Gaya Kognitif. e-Journal Program Pascasarjana Universitas Pendidikan Ganesha Program Studi Penelitian dan Evaluasi Pendidikan. (4). 1-11.

Paramitha, L. A, Sumarjono, dan Parno. 2014. Pengaruh Model Pembelajaran Berbasis Masalah (PBM) Terhadap Keterampilan Berpikir Kreatif Dan Metakognisi Pada Pembelajaran Fisika Siswa Kelas X SMA Negeri 2 Lumajang. Tesis: FMIPA Universitas Negeri Malang.

Piaw, C. Y. 2011. Hindrances to Internal Creative Thinking and Thinking Styles of Malaysian Teacher Trainees in the Specialist Teachers' Training Institute. Procedia Social and Behavioral Sciences. 15: (4013-4018).

Piaw, C. Y. 2014. Relationship Between Thinking Styles and Ability to Pay Attention of Malaysian Male and Female Student Teachers. Procedia - Social and Behavioral Sciences. 116: (4839 4843). 
Rusnayati, H dan Prima, E. C. 2011. Penerapan Model Pembelajaran Problem Based Learning dengan Pendekatan Inkuiri Untuk Meningkatkan Keterampilan Proses Sains dan Penguasaan Konsep Elastisitas pada Siswa SMA. Prosiding Seminar Nasional Penelitian, Pendidikan dan Penerapan MIPA, Fakultas MIPA, Universitas Negeri Yogyakarta, 14 Mei 2011.

Sahin, M. 2010. Effects of Problem-Based Learning on University Students' Epistemological Beliefs About Physics and Physics Learning and Conceptual Understanding of Newtonian Mechanics. J Sci Educ Technol. 19: 266-275.

Selcuk, G. S. 2010. The Effects of Problem-Based Learning on Pre-Service Teachers' Achievement, Approaches and Attitudes Towards Learning Physics. International Journal of the Physical Sciences. 5 (6): 711-723.

Sharma, P. dan Neetu. 2011. A Study of Learning-Thinking Style of Secondary School Students In Relation to Their Academic Achievement. International Journal on New Trends in Education and Their Implications. 2. 4. (12): 1309-6249.

Sitompul, J. N. 2013. Pengaruh Strategi Pembelajaran dan Gaya Berpikir Terhadap Hasil Belajar Fisika Siswa SMPS Ahmad Yani Binjai dan SMPS Gajah Mada Binjai. Tesis: Program Pascasarjana Universitas Negeri Medan.

Sudjana, N. 2011. Penilaian Hasil Proses Belajar Mengajar. Bandung: Remaja Rosdakarya.

Sugiyatno. 2010. Pembelajaran Fisika Berbasis Masalah Melalui Metode Proyek dan Pemberian Tugas Ditinjau dari Gaya Berpikir dan Kreativitas siswa. Tesis: Universitas Sebelas Maret Surakarta.

Sugiyono. 2009. Metode Penelitian Pendekatan Kualitatif, Kuantitatif dan R\&D. Bandung: Alfabeta.

Sulaiman, F. 2013. The Effectiveness of PBL Online on Physics Students' Creativity and Critical Thinking: A Case Study at Universiti Malaysia Sabah. International Journal of Education and Research. 1. (3). 1-18.

Suprijono, A. 2011. Cooperative Learning: Teori dan Aplikasi PAIKEM. Yogyakarta: Pustaka Pelajar.

Utomo, T, D. Wahyuni, S. Hariyadi. 2014. Pengaruh Model Pembelajaran Berbasis Masalah (Problem Based Learning) Terhadap Pemahaman Konsep dan Kemampuan Berpikir Kreatif Siswa. Jurnal Edukasi UNEJ. I (1): 5-9.

Xie, Q. Xiangping, G. dan Ronnel B. K. Thinking Styles in Implicit and Explicit Learning. Learning and Individual Differences. 23. (267-271).

Zaraturrahmi. 2016. Pengembangan Lembar Kerja Peserta Didik (LKPD) Berbasis Masalah pada Pokok Bahasan Cermin untuk Meningkatkan Motivasi dan Hasil Belajar Siswa. Tesis. Tidak Dipublikasi. Program Magister Pendidikan IPA Universitas Syiah Kuala. 
